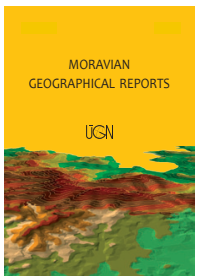

\title{
Population potential within the urban environment and intra-urban railway network opportunities in Bratislava (Slovakia)
}

\author{
Pavol Ďurček ${ }^{\text {a* }}$, Marcel Horňák ${ }^{\text {a }}$
}

\begin{abstract}
Urban environments in post-socialist cities have generated new challenges for urban planners and decision makers. As one example, the transport infrastructure of Bratislava has not been adjusted with respect to increasing mobility and the transit problems of its intra-urban environment. An upgrading of the conventional railway networks within the city is one of the major opportunities which might considerably improve public transit capacities available for both intra-urban and regional (suburban) transport flows of passengers. Relevant studies on the population potential of residents supporting such upgrades are still lacking. In addition, a detailed database on population distributions within the intra-urban environments of Slovak cities is not yet available. Therefore, this paper attempts to introduce one of the possible methodological approaches leading to an estimation of population potential as an elementary precondition of intra-urban railway traffic effectiveness, in a society where a detailed database on population distribution is not available.
\end{abstract}

Keywords: accessibility, population potential, intra-urban railway transport, GIS, Bratislava, Slovakia

Article history: Received 16 June 2016; Accepted 20 November 2016; Published 30 December 2016

\section{Introduction}

Intra-urban transport networks and their upgrading represent one of the pressing issues discussed in geographic, economic and other scientific periodicals. In Bratislava (the capital city of Slovakia), debates on upgrading the city transport system have recently become very frequent, too. As a result of this, a new Master Transport Plan of the Capital City was elaborated and approved by the city authorities in 2015 .

Bratislava is a typical example of a post-socialist city, searching for tools and policies aimed at coping with growing intra-urban mobility demands and flows. Moreover, according to recent studies (e.g. Šveda, 2011; Hardi, 2012), the intensification of suburbanisation processes in the Bratislava region after 2000 has generated a growth of commuter flows between the city and its hinterland. In addition, considering growing transit traffic (especially road transit) passing through the urbanised area of Bratislava, the imbalance between increasing mobility and traffic demands and the limited capacity of the urban transport infrastructure has been increasing constantly (CDV, 2016).

Our intention is to demonstrate one of the possible approaches to intra-urban transport infrastructure accessibility research to show some of the opportunities for the practical utilisation of scientific geographical research within a GIS environment. Michniak (2003) distinguishes among three basic elements of accessibility: (1) accessibility as represented by an individual, community or any other group of persons; (2) the constitution of an accessibility object (the target site): and (3) a transport link between initial and target points of accessibility carried out in existing transport networks. This paper is principally focused on the first element, while the latter ones play only marginal roles in our study.

The main aim of the paper is the quantification of the size of the population residing in sites adjacent to railway stations located in Bratislava city. Such a quantification process may result in a more accurate estimation of populations concentrated near railway stations, which allows for the definition of the potential of the stations for intra-urban traffic purposes more precisely. Recent discussions on policies aimed at a higher involvement of railway network capacities in intra-urban passenger transport performance in Bratislava have inspired us to show and employ one of the possible methodological approaches to the issue. In this study, two different approaches or variants will be shown: in addition to the existing railway stations' potential for intra-

\footnotetext{
${ }^{a}$ Department of Human Geography and Demography, Faculty of Natural Sciences, Comenius University in Bratislava, Slovakia (*corresponding author: P. Durček, email:durcek@fns.uniba.sk)
} 
urban transport, the potential of railway stations planned in Bratislava's railway network upgrading projects will be considered. The potential of railway stations was calculated as the number of inhabitants residing within 15 minutes travel time from the nearest railway station. The resident populations within the 15-minutes interval will be scanned for two different modes of transport: walking and using public transport. We assume that within a densely urbanised environment, these two modes of transport play a basic role in everyday access to intra-urban railway nodes and stations (Brons et al., 2009).

Unlike most Western European cities, Bratislava has still not developed a relevant infrastructure suitable for the daily use of bicycles in passenger traffic. Passenger car transport was not considered because the existing railway stations in Bratislava are usually not equipped with sufficient car parking capacities. Additionally, Bratislava has not developed a system of park-and-ride (hereinafter P\&R) capacities adjacent to railway stations so far (according to CDV 2016, the P\&R sites are supposed to be at the terminal stops of tram lines). Our approach is rather simplified, but our main intention is to verify a scientific method to facilitate an accurate assessment of the resident population potential related to an intra-urban transport network in a society where a population register database has not been developed.

\section{Theoretical background}

\subsection{Accessibility to transport infrastructure in scientific research}

The phenomenon of accessibility has been examined frequently in various studies. The methodology used in accessibility research and the graphical visualisation of population potential related to transport networks have been elaborated in numerous scientific papers and studies (see e.g. Brainard et al., 1997; Kwan, 1998; Jiang et al., 1999; Geurs and Ritsema van Eck, 2001). The abovementioned issues are also subject to systematic research in Slovakia, where several valuable studies emerged. For instance, Križan and Gurňák (2008) describe a wide spectrum of cartographic tools for the assessment and visualisation of accessibility measures, preceded by studies presenting some of the cartographic methods of accessibility evaluation published by Kusendová and Szabová (1998) and Kusendová (2002).

Several previously published application studies showing detailed analyses of existing transportation systems and networks were also valuable for our research. Questions of the optimal accessibility of public transport in comparison with individual transport were disputed by Morris et al. (1979) and later by numerous studies (such as Handy and Niemeier, 1997; Geurs and Van Wee, 2004; Boruta and Ivan, 2010; Ivan and Tesla, 2015). With respect to conditions in Slovakia, Hejhalová (2010) tried to evaluate standards of public transport service quality and availability at a regional scale, emphasising the importance of public transport upgrading to improve its attractiveness. Special attention has also been paid to the process of the formation of integrated public transport networks, which is considerably belated compared to Western European countries (Bulíček and Mojžiš, 2008; Bulíček, 2008).

The accessibility to railway networks has been subject to research from various perspectives as well. A seminal study was carried out by Kotovaara et al. (2011), who examined how population increase/decrease might be affected by accessibility to both railways and road networks. General methods assessing railway network accessibility and population distribution in relationship to railway infrastructure have been verified by numerous studies (see for example, Zhang et al., 1998; Horňák, 2004; Willigers et al., 2007; Horňák, 2008). In Slovakia and the Czech Republic, several studies on the accessibility of railways at the national level have appeared (Horňák, 2003; 2004; Michniak, 2006; Pšenka, 2009), including railway network distribution assessment in relationship to economic activities (Horák et al., 2004; Michniak, 2014). A special focus on accessibility in public transport infrastructure was presented in several important studies by Givoni and Rietveld (2007), Brons et al. (2009), Marada and Květoň (2010) and Boruta and Ivan (2010).

The intra-urban accessibility of infrastructure is the focus of this paper. Following some classical studies (e.g. Hanson and Schwab, 1987; Helling, 1998; Kwan, 1998), the accessibility of transport elements (and specifically of public transport networks) has been analysed and applied in Bratislava. The first assessment of intra-urban accessibility of railway stations within the city of Bratislava by means of GIS tools was carried out by Križan and Tolmáči (2008a). Two different accessibility measures were applied by these authors to examine the overall accessibility of railway stations from individual urban statistical units, enriched by a field questionnaire survey. The detailed population distribution related to the railway network was not shown in that paper, however, due to the missing detailed database of residential addresses. The analysis utilised 2001 census data, which allowed only a rough picture of population distribution in the urban environment, as the census data relate to statistical units covering often quite large intraurban areas. Nevertheless, the above- mentioned study is a valuable example of a GIS-based analysis, even though the lack of accurate data led to limited results.

In addition, specific attention should be paid to the research by Kraft and Blažek (2012), who applied an approach to intra-urban public transport network accessibility in the city of České Budějovice (Czech Republic). The calculation of public transport network nodes accessibility within the urban environment used in this case was similar to what is applied in the current project. The main difference lies in the data sources on population distribution within the area of the city, as a detailed database on residential addresses (undisclosed data from the domicile register) was available for České Budějovice. With this database, the authors had a perfect opportunity to show the distribution of the city's residents and to analyse their accessibility to the urban transportation system.

As shown above, the accuracy of input data has a considerable effect on the final results, if the intra-urban accessibility of transport infrastructure is taken into consideration. In contrast with national or regional level studies, the measurement of an intra-urban level of accessibility requires specific detailed input data. Following Kraft and Blažek (2012), but lacking sufficiently detailed data, we elaborate a method leading to more accurate results. Hence, a lot of attention is paid to database creation and methodology in this paper.

\subsection{Railway systems in the service of intra-urban traffic demands}

Generally, rail networks (both conventional railways as well as segregated urban rails) in urban areas in Europe and North America have their roots basically in the $19^{\text {th }}$ century 
industrial revolution, when the development of railways became an inevitable precondition of economic development, encouraging an unprecedented growth of metropolitan areas. The renaissance of rail systems within large urban areas was seen in the second half of the $20^{\text {th }}$ century as one of the efficient solutions to tackle rising traffic congestion (Docherty et al., 2008); however, as claimed by Lane (2008), the urban rail redevelopments in American and European metropolitan areas rest on significantly different priorities.

The process of urban rail network revitalisation has been seen worldwide, although some infrastructure-related specifics may be observed in relationship with traditional national or local policies, which led to the development of more or less peculiar rail technologies applied in individual countries or cities. In some metropolitan areas, redevelopment of existing rail systems has been crucial (e. g. the S-bahn network in Berlin: Peters, 2010). Elsewhere (for example in British cities), the redevelopment of existing rail networks has been accompanied by a vast construction of new rail system (Edwards and Mackett, 1996). The development of rail systems in the environment of what was the former Czechoslovakia has recently been well documented by Seidenglanz et al. (2016), who emphasise that the Czechoslovak metropolitan areas (including Bratislava) witnessed a considerable development of light rail systems (based on fast urban trams) typical for many other European areas.

The impact of the intra-urban locations of inter-city railway stations on their surrounding urban environments may be immense (Ahlfeldt, 2011). As indicated by Peters (2009, p. 177), "the high-profile redevelopment of central rail stations and their surrounding areas in major cities... underlines the reinvigorated significance of rail-based infrastructures in the post-modern, postindustrial, postFordist urban regional fabric". This aspect of inter-city railway nodes is not in the scope of this study. Nevertheless, we want to emphasise that by strengthening the position of conventional railway stations within the urban environment of Bratislava, the redevelopment of the neighbouring areas could bring further benefits for the city. The process of a full integration of conventional railways into the public transport network in the city of Bratislava has been a matter of numerous political discussions. To date, however, no definitive planning document has been produced on a final solution for the conventional railway network. According to an official announcement of the national railway network operator (Železnice Slovenskej republiky), the process of elaboration of a feasibility study on the railway nodes of Bratislava has been launched recently (www.zsr.sk).

\section{Research methodology}

\subsection{Database preparation}

MAPZEN (2015) is an Internet portal where databases on transport networks and land-use categories are available, even for highly urbanised areas. This internet source is utilised also by the well-known OpenStreetMap portal (2015). For our purposes, the following map layers were downloaded in Shapefile (SHP) format (as of February $\left.1^{\text {st }}, 2015\right)$ : existing buildings layer; transport networks layer (pedestrian walkways, roads, railways, etc.); and landuse layer and administrative units. A map layer of basic residential units (BRU, administered by the Statistical Office of the Slovak Republic as elementary statistical units), adopted from the study of Garajová (2015), was utilised as the second input database. This map layer included data on population sizes in individual BRUs (as of May $21^{\text {st }}, 2011$ ), based on the official 2011 population census, published in Štatistický lexikón obcí Slovenskej republiky 2011 (Podmanická et al., 2014).

All steps leading to the development of the source database as described below have been executed in the ArcGis 10.1 environment. The selection of geo-referenced data covering the territory of Bratislava city was the very first step, utilising the "CLIP" tool. From source map layers, we defined the administrative territory of Bratislava city using the proper map layer of administrative borderlines.

Two main elements were crucial in the process of input database adaptation. First, detailed spatial data on the resident population distribution were necessary. These data allowed us to identify the number of residents living in particular accessibility zones surrounding railway stations in the city. Second, to derive realistic distances to measure accessibility to individual railway stations, relevant communication lines (pathways and public city transport networks) were identified.

The steps leading to an accurate estimation of the population sizes were as follows. Data on the location (addresses) of residents are permanently collected by the Central Population Register, which has already initiated the development of a so-called "address points" database covering the number of citizens residing at each address. This database is not available to the public, however, as its development is still in progress. Hence, we decided to apply a spatial approximation approach to create our own original database of the resident population distribution. To achieve this, map layers of existing buildings and BRUs ${ }^{1}$ (including numbers of inhabitants as of 2011) were used. The basic principle in this approximation rests on the number of residents related to individual buildings. In this simple procedure, we had to face several problems. Not all buildings in the urban area are residential. Numerous buildings serve as industrial structures, shopping centres, schools, offices, etc. To distinguish among the principal functions of each building, the purpose of use attributed to each building in the map layer was used ${ }^{2}$. Based on this, buildings utilised primarily for residential purposes were selected for further data processing ${ }^{3}$. The selection procedure is schematically shown in Figure 1. In the following step, the layer of residential buildings was merged with the layer of BRUs using the "Join Data" tool.

\footnotetext{
${ }^{1}$ The BRU layer represents the most detailed freely available database on population distribution in the urban environment of Bratislava.

2 abandoned; apartments; barn; bridge; bunker; cabin; castle; cathedral; civic; collapsed; commercial; construction; container; detached; dormitory; garage; garages; greenhouse; hangar; hospital; hotel; house; houseboat; hut; chapel; church; industrial; kindergarten; manufacture; monastery; office; palace; post office; primary; public; residential; restaurant; retail; roof; ruins; shelter; shop; school; stadium; store; supermarket; terrace; theatre; tower; train station; transportation; university; utility; warehouse; other.

${ }^{3}$ apartments; house; residential
} 


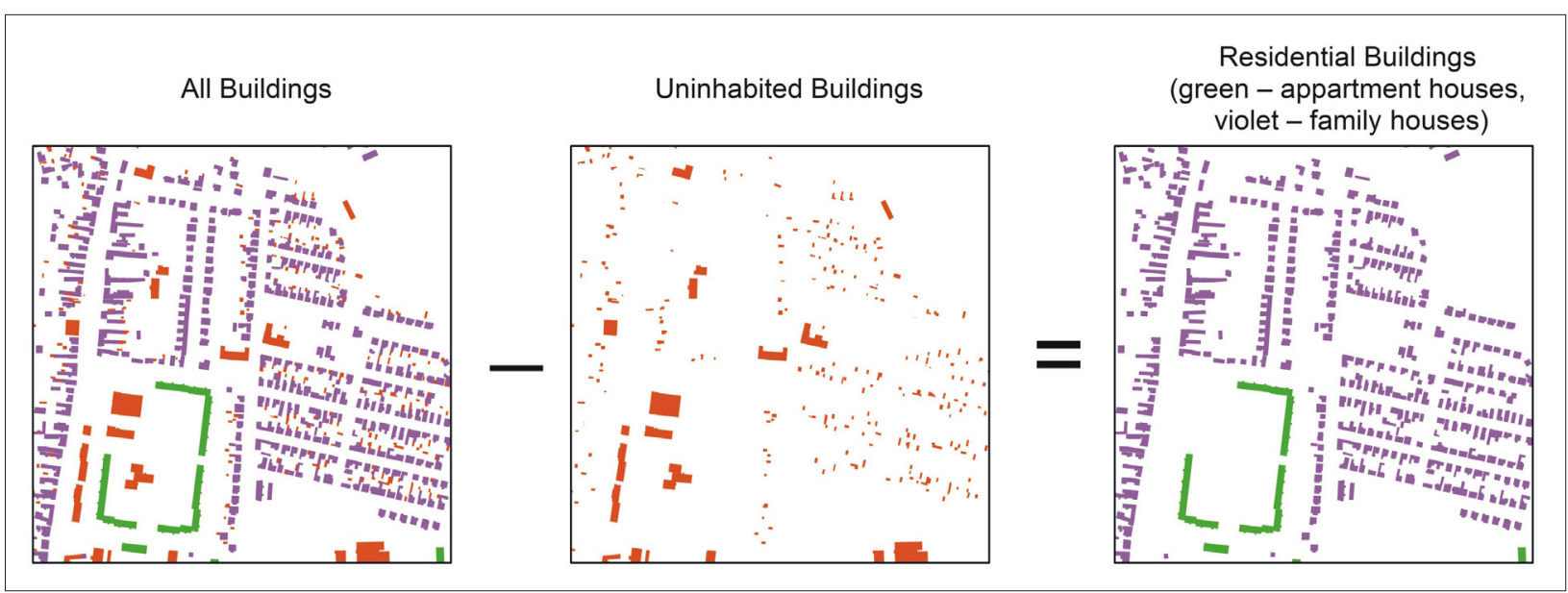

Fig. 1: Scheme on the selection of residential buildings Source: MAPZEN 2015, authors' compilation

The redistribution of the population numbers of each BRU into individual residential buildings was carried out based on the proportionate area of each building. Applying the "Calculate geometry" tool, the area $\left(\mathrm{m}^{2}\right)$ of the plot of each residential building was calculated. The difference in the number of flats and floors (and thus residents) between standard family houses and apartment blocks may be significant, however, and so an estimation of the number of floors was carried out. No such official database is available; therefore we decided to estimate the number of floors based on a coefficient derived from a database of the internet portal ASB (2014). According to this database, the number of floors in a multi-storey apartment building in Bratislava ranges from 3 to 35, but 9 on average, while family houses have 2 floors on average. Therefore, the ground floor area of apartment houses and family houses was multiplied by 9 and 2 , respectively. In the next step, the number of inhabitants residing in each BRU was distributed proportionally into residential buildings according to the following equation:

$$
P O_{i j}=R_{i j} \cdot \frac{P O_{j}}{\sum_{j} R_{i j}}
$$

where $\mathrm{PO}_{i j}=$ number of residents in building $i$ located in basic residential unit (BRU) $j, \mathrm{R}_{i j}=$ ground-plot area of building $i$ located in BRU $j$ (area after multiplying), and $\mathrm{PO}_{j}=$ total number of residents of BRU $j$.

Having estimated the numbers of residents per residential building, a centroid for each building was generated by using the "Feature to Point" tool. In the following steps, the centroids are referred to as centres of population masses residing in respective buildings.

The way in which proper communication/mobility networks within the city were handled in this analysis is as follows. Unlike the above description of estimating population distribution, no approximation was necessary. Current map layers of communication networks in Bratislava were downloaded from the MAPZEN portal.
The source data for the map layer contains 27 types $^{4}$ of networks in total. For our purposes, only selected types were considered.

Following the main objectives of the paper, only two types of transport were used to measure accessibility of railway stations. We did not include individual car transport, as its use in intra-urban environments of middle-sized and large cities (including the city of Bratislava) is quite limited (Gardner and Abraham, 2007; Givoni and Rietveld, 2007), especially if access to railway stations is considered (lack of parking capacities). Based on this argument, network segments utilised by public city transport ${ }^{5}$ and footpaths ${ }^{6}$ for pedestrians were extracted for further examination. This step is illustrated by Figure 2 .

\subsection{Methods}

The methods applied in this paper cover three main aspects: (1) methods focused on the selection of specific accessibility zones will be explained; (2) the delimitation of particular accessibility zones and identification of population masses within the zones will be described; and (3) different variants of the locations of railway stations will be subjected to research.

The population potential for intra-urban railway transport has been estimated as the mass of population residing near railway stations. To do this, the question of adequate distance ("What is near?") was resolved first for both ways of accessing the railway station, i.e. on foot as well as by city public transport. Based on studies by various authors (e.g. Hensher, 2001; Seidenglanz et al., 2016), for those travelling daily by high-capacity intra-urban networks (metro, light railways, etc.) an acceptable time-accessibility to the nearest station is usually up to 15 minutes, which can also be applied to the territory of Bratislava. Within the 15-minutes time-interval, an average walking speed of $4 \mathrm{~km} /$ hour allows one cover about 1,000 metres. This distance will be used to generate walking distance belts around the railway stations. For public transport accessibility, the same time interval (15 minutes) was applied, but accessibility of the inner-city

\footnotetext{
${ }^{4}$ bridleway; cycleway; disused; footway; living street; motorway; motorway link; path; pedestrian; pier; primary; primary link; raceway; rail; residential road; secondary; secondary link; service; steps; tertiary; tertiary link; track; tram; trunk; trunk link; unclassified

${ }^{5}$ motorway; motorway link; primary; primary link; residential road; secondary; secondary link; tertiary; tertiary link; tram

${ }^{6}$ footway; living street; path; pedestrian; pier; service; steps
} 


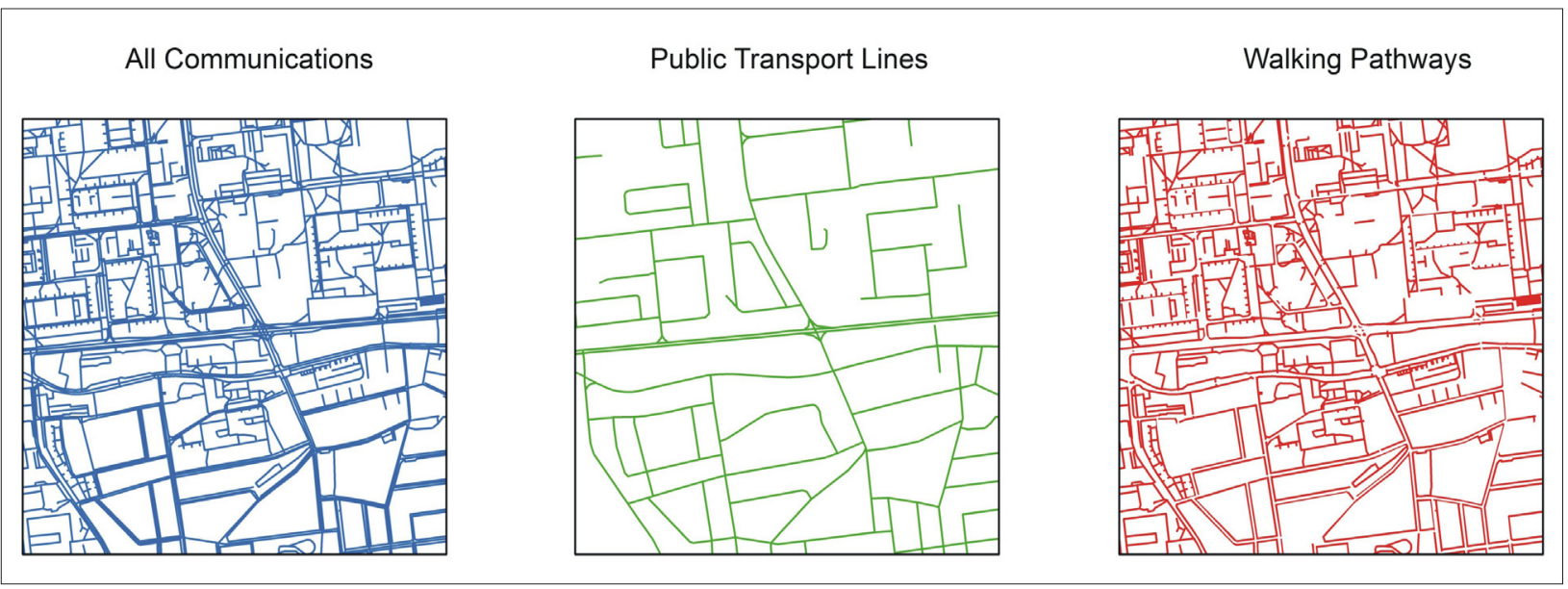

Fig. 2: The selection of proper ground communication networks available for pedestrians and by means of public transport. Source: MAPZEN 2015, authors' compilation

public transport stops was taken into consideration, too. The scheme in Figure 3 shows the process of accessibility zone delimitation in a simplified form.

Again, a walking time of 5 minutes necessary to reach the nearest public transport stop was considered (according to Hejhalová, 2010). For transfer between inner-city transport and train, the same time was taken into account (in Bratislava, railway and inner-city transport networks including trams - have not been integrated at present: they use fully separated infrastructure), as recommended by Hejhalová (2010). Finally, the rest of the 15 minutes covers a 5-minutes journey on a bus/trolleybus/tram within the inner city public transport network. The estimation of average travel speed $(24 \mathrm{~km} / \mathrm{h})$ by means of the city public transport was based on real-time measurement carried out on public transport vehicles (see Annex 1). At an average speed of $24 \mathrm{~km}$ per hour and with a 5 minutes journey, an accessibility belt width reaches to about $2 \mathrm{~km}$. This distance was detected in the existing ground communication network.

The technical details of the creation of individual buffer zones can now be detailed. Within the GIS environment of ArcGis 10.1, layers of railway stations, city public transport network and footpaths were uploaded for further analyses.
To generate individual accessibility buffer zones, tools included in the "Network Analyst" package were utilised. For a further analysis of both layers, a so-called Active Network Dataset was created through the "Built Network Dataset" tool. Such a geo-statistical database consists of junctions and edges, where edges represent communication links and junctions the real nodes in the networks. The transformation of the network is illustrated in Figure 4.

After creation of the Active Network Dataset, the delimitation of accessibility zones was carried out. At the first step, locations of interest ('Facilities') were set in the database, represented by a layer of points where each point is located in the centre of the railyard of each station. Subsequently, via the "Analysis Settings" tab, the accessibility values for both buffer zones were set through the "Properties" choice within the "Service Area" solver. For walking travellers, a distance of 1,000 metres ${ }^{7}$ was used and analogously, a distance of 2,000 metres ${ }^{8}$ was applied for city public transport users. The following settings were applied through the "Polygon Generation" settings tab, where the choice of "Generalised" was selected. For the "Trim Polygon" tool, distances of 100 metres and 300 metres were applied for footpaths and for the city public transport

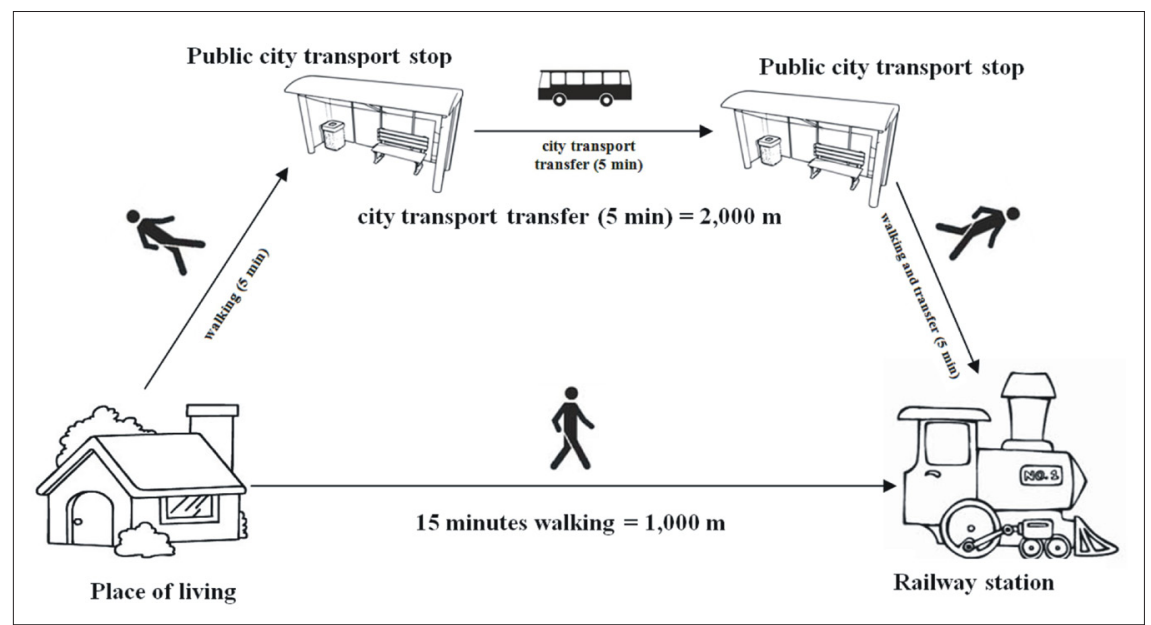

Fig. 3: The process of delimitation of accessibility zones around railway stations applying both walking and public transport transfers. Source: authors' compilation

${ }^{7} 1,000 \mathrm{~m}$ distance is equal to 15 minutes of walking at a speed of $4 \mathrm{~km} / \mathrm{h}$

${ }^{8} 2,000 \mathrm{~m}$ distance is equal to 5 minutes of journey by city public transport at speed of $24 \mathrm{~km} / \mathrm{h}$ 
network, respectively. In the "Multiple Facilities Options", the item "Not Overlapping" was selected. In "Overlap Type", the "Ring" tool was used. After all settings, individual buffer zones of accessibility were generated via the "Solve" command. Figure 5 demonstrates the whole process.

Through the "Export Data" command, a separate map layer of buffer zones was created. A map layer of residential buildings (represented by points with respective population masses) was uploaded into ArcGis software. From this layer, only buildings located within the individual accessibility zones were selected using the "Select by Location" tool. The final summarisation of all inhabitants residing in the buildings located in particular accessibility zones revealed the masses of population in individual zones surrounding relevant railway stations.
Finally, we should explain the principles used in the selection of railway stations network variants which were used for the delimitation of accessibility zones. The main goal of this paper is the estimation of the population potential of conventional railways for intra-urban public transport purposes. Hence, our intention was to cover two variants of the railway station network. The first variant includes the existing network of railway stations used currently for intraurban transportation ${ }^{9}$

The second variant includes all projects of future railway stations in the west-east railway axis that have already been elaborated. For all of these projects, locations of future stations have already been approved in a project titled "ŽSR, Terminály integrovanej osobnej prepravy v Bratislave, úsek Devínska Nová Ves-Bratislava-Hlavná stanica-Podunajské

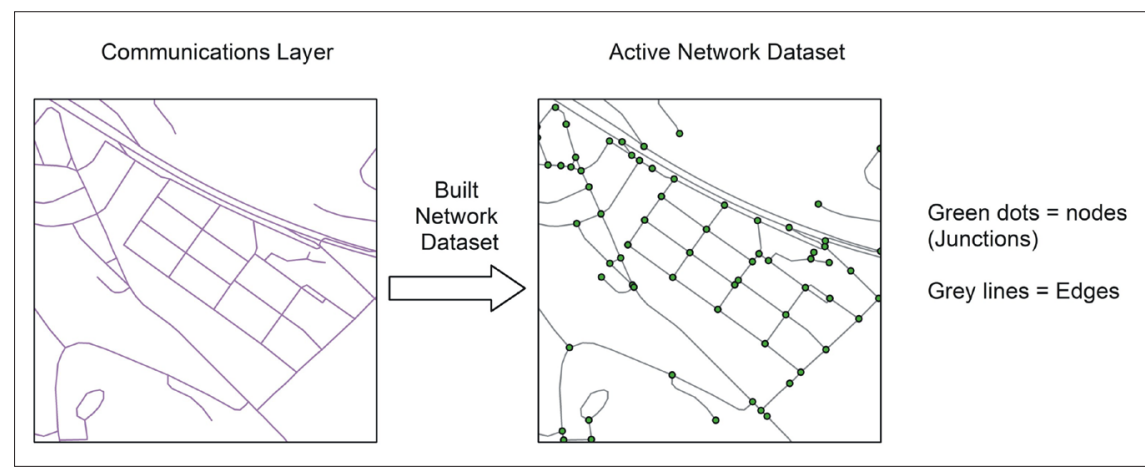

Fig. 4: An example of Active Network Dataset generation.

Source: MAPZEN 2015, authors' compilation

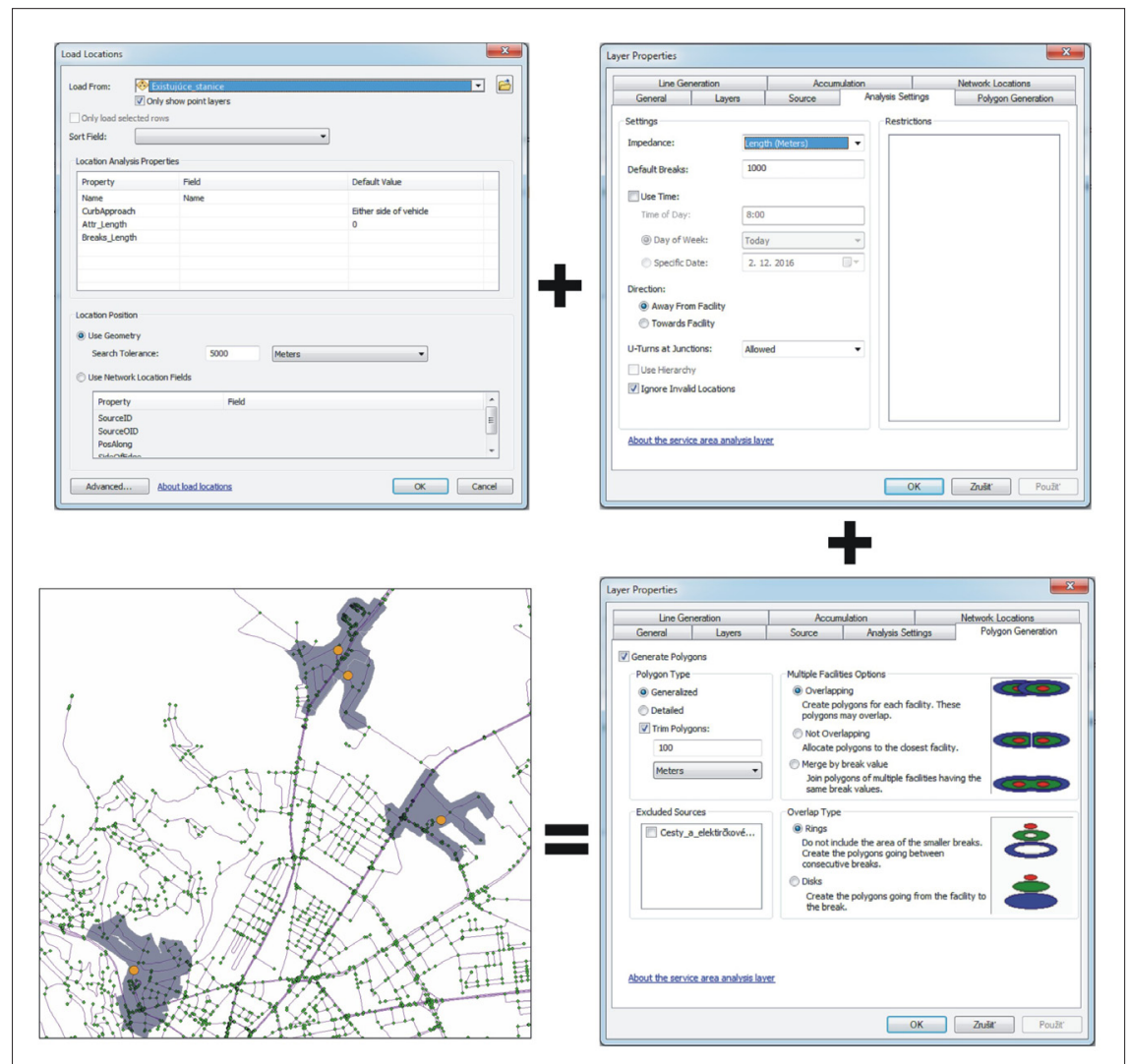

Fig. 5: The setting of a "New Service Area".

Source: MAPZEN 2015, authors' compilation

\footnotetext{
${ }^{9}$ A railway station serving for intra-urban transport is a station located within the urban area of Bratislava, with a currentlyoperated direct train connection to any other railway station in Bratislava
} 
Biskupice (Terminals of integrated passenger transport in Bratislava, section Devínska Nová Ves-Bratislava-Hlavná stanica-Podunajské Biskupice)", realised by Railways of the Slovak Republic (the state railway infrastructure manager, see ŽSR..., 2016). The railway passenger terminals covered by this project are recently in various stages of preparation. Furthermore, except for these planned stations, we included also other existing stations that are not used for intra-urban transportation currently. Figure 6 illustrates the locations of railway stations in the city in both variants of railway network development. For each variant and for each station, accessibility zones were generated with their relevant numbers of residents.

We admit that the methodology described above rests on a rather simplified model. Certain simplifications may lead to results that can raise some questions and doubts. In contrast, we are trying to develop a method for the measurement of the population potential for transport networks in a social environment where detailed statistics on the resident population based on a domicile register database are still not available. Undoubtedly, with appropriate tools and data, individual steps of our approach may be developed further to gain more accurate results.

\section{Empirical analysis and findings}

The accessibility of existing intra-urban railway stations is shown in Table 1. Our analyses reveal that over $27 \%$ of the residents of Bratislava are located up to 15 minutes to the nearest station, but only $7 \%$ are within a walking distance. The proportions seem to be rather low, but a detailed assessment (see Fig. 7) provides some explanation.

Not surprisingly, the greatest population concentration is observed around Bratislava-Hlavná stanica (BratislavaCentral station), as it is located near the city centre. This accessibility zone covers densely urbanised built-up districts with both family houses and apartment houses, which correspond with high resident population density. Although the accessibility zone of the Lamač station (see Tab. 2) embraces a large portion of transit corridors and grassed and forested areas, the high-rise apartment houses in the neighbourhood are home to numerous residents. Similarly, Podunajské Biskupice station covers partly a bare land, with a high potential for residential development in the future. Nové Mesto station might play the role of a secondary central station (Whitehand, 1967), as it is located in the neighbourhood of a business district, shopping zone and industrial district.

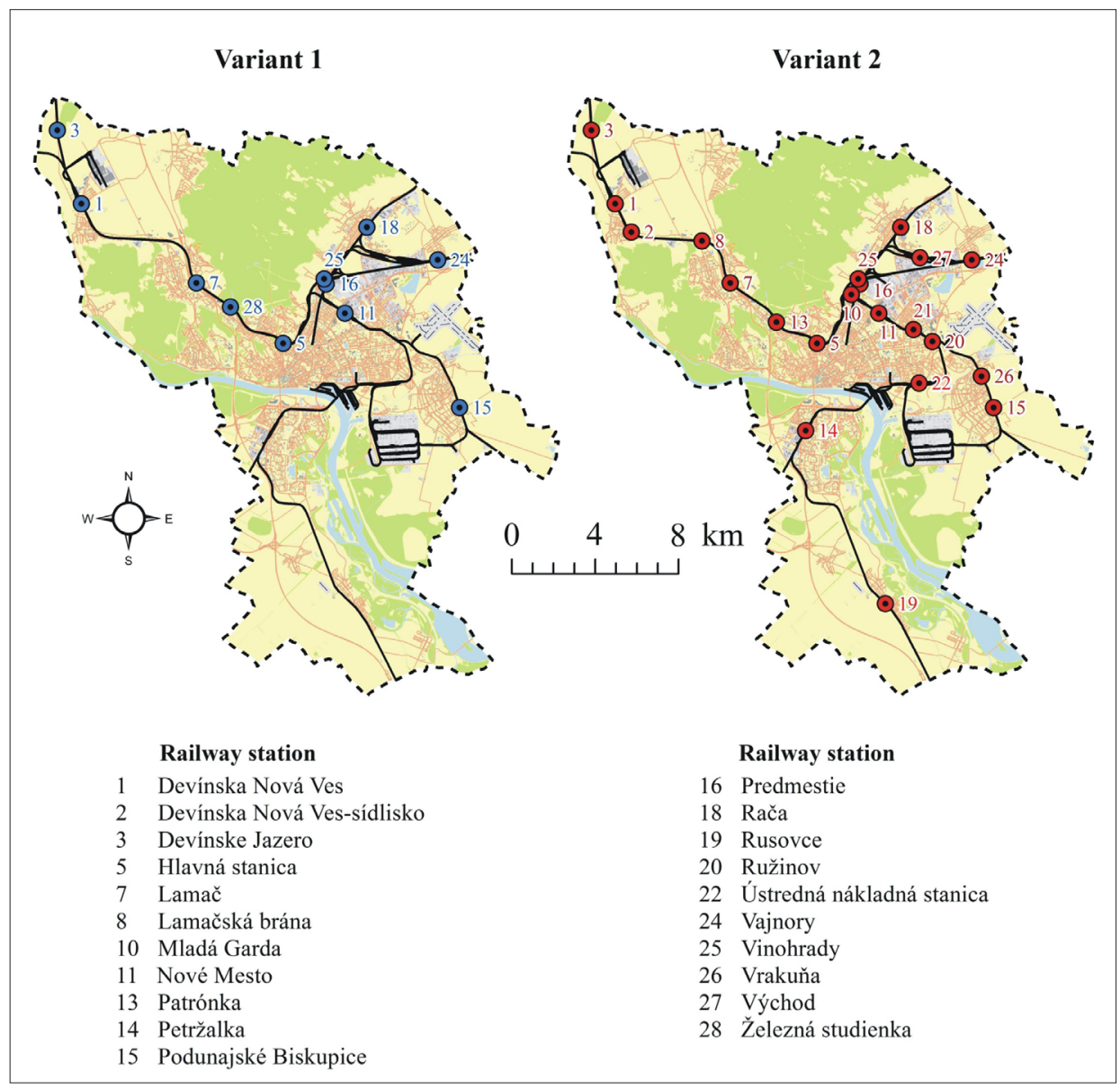

Fig. 6: The location of railway stations in Bratislava: Two variants

Sources: Location of railway stations: CDV, 2016, ŽSR, 2016; Map layers: MAPZEN, 2015

Notes: 1 - The currently existing stations of Východ, Petržalka, Ústredná nákladná stanica, Rusovce were included in Variant 2 only, as these stations are not currently serviced by any passenger trains providing connection within Bratislava; 2 - Železná studienka Station is not included in Variant 2 because projected Patrónka Station will be located nearby (approximately 1,000 metres). Patrónka station will enable both better connections to the city public transport network and will be located in an area with higher population concentration. According to CDV (2016), Železná studienka Station will play only a marginal role in the railway network, operating only for occasional trains and tourist services These were the main reasons why this station was not included in Variant 2; 3 - stations "Filiálka" and "Letisko" were excluded, as the TEN-T 17 project had been suspended). 
Other stations (such as Rača, Železná studienka or Devínska Nová Ves) are positioned in neighbourhoods on the outskirts of the city with less concentrated and partly sparsely populated residential districts. Some of these areas are former rural settlements integrated into the city structure in the process of intensive urbanisation in the $20^{\text {th }}$ century, or they represent suburban neighbourhoods (especially Devínske jazero or Vajnory stations) within the city's administrative area, where family houses are the dominant form of housing (see Šveda, 2011). Vinohrady

\begin{tabular}{lrrrrrr}
\hline \multirow{2}{*}{ Railway stations } & \multicolumn{2}{c}{ Accessibility zones - numbers of residents } \\
& \multicolumn{2}{c}{$0-1,000 \mathrm{~m}$} & \multicolumn{2}{c}{$1,001-2,000 \mathrm{~m}$} & \multicolumn{2}{c}{ Total $(0-2,000 \mathrm{~m})$} \\
\cline { 2 - 7 } & \multicolumn{1}{c}{ abs. } & rel. $(\%)$ & abs. & rel. (\%) & abs. & rel. (\%) \\
\hline Devínska Nová Ves & 2,392 & 0.58 & 3,562 & 0.87 & 5,956 & 1.45 \\
Devínske Jazero & 0 & 0.00 & 52 & 0.01 & 52 & 0.01 \\
Hlavná stanica & 6,663 & 1.62 & 22,332 & 5.43 & 28,995 & 7.05 \\
Lamač & 5,560 & 1.35 & 17,215 & 4.19 & 22,776 & 5.54 \\
Nové Mesto & 2,130 & 0.52 & 12,255 & 2.98 & 14,385 & 3.50 \\
Podunajské Biskupice & 2,682 & 0.65 & 13,945 & 3.39 & 16,627 & 4.04 \\
Predmestie & 2,111 & 0.51 & 281 & 0.07 & 2,392 & 0.58 \\
Rača & 4,063 & 0.99 & 8,908 & 2.17 & 12,970 & 3.15 \\
Vajnory & 1,688 & 0.41 & 1,351 & 0.33 & 3,039 & 0.74 \\
Vinohrady & 347 & 0.08 & 3,240 & 0.79 & 3,587 & 0.87 \\
Železná studienka & 240 & 0.06 & 1,082 & 0.26 & 1,322 & 0.32 \\
\hline Total - existing stations & $\mathbf{2 7 , 8 6 6}$ & $\mathbf{6 . 7 8}$ & $\mathbf{8 4 , 2 2 4}$ & $\mathbf{2 0 . 4 8}$ & $\mathbf{1 1 2 , 0 8 9}$ & $\mathbf{2 7 . 2 6}$ \\
\hline
\end{tabular}

Tab. 1: Number of residents in particular accessibility belts surrounding railway stations currently serviced by intraurban passenger trains (Variant 1). Source: authors' calculations based on the 2011 population census

Notes: Abs. = absolute numbers; Rel. = relative proportions. Relative values are derived from the total population of Bratislava

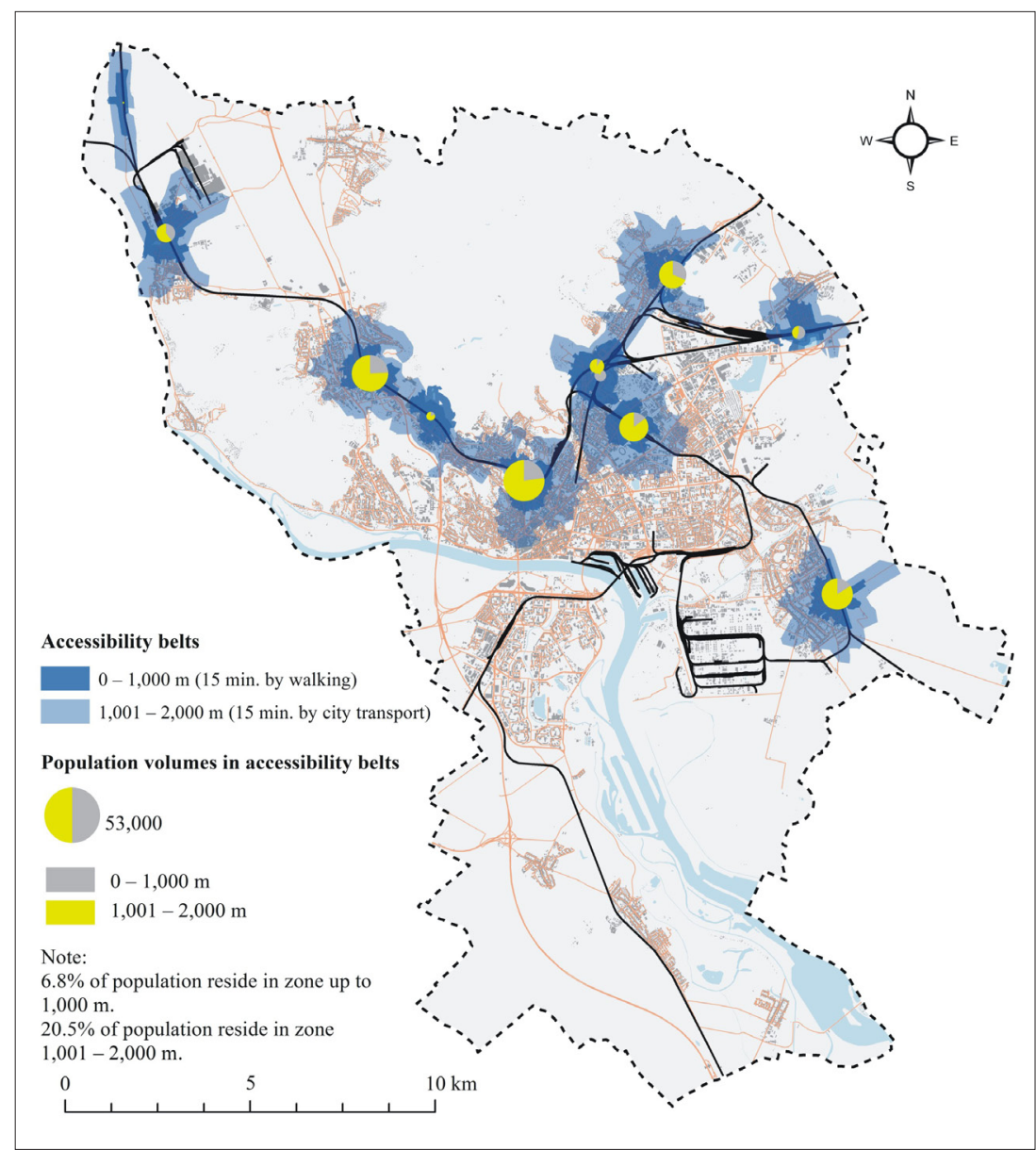

Fig. 7: The accessibility of railway stations currently serviced by intra-urban passenger trains (text: Variant 1) Sources: Locations of railway stations: CDV, 2016; ŽSR..., 2016; Map layers: MAPZEN, 2015. 
and Predmestie stations are surrounded by more or less industrial districts but they have a high potential as public transport transfer nodes.

As stated above, the attractiveness of some of the existing railway stations in Bratislava is limited by their position. Some of them are positioned in sparsely populated districts or in locations with poor access for numerous residents (peripheral locations, industrial districts, bare areas). On the other hand, stations located in the city districts to the south (see Fig. 8) lack any access to railway stations, but this is due to the fact that no passenger trains are operated in this part of the intra-urban railway network. The only station serviced with regular passenger trains is Bratislava-Petržalka, but this station is the terminal for regional expresses to/from Austria (Vienna) and there is currently not a single passenger train link from this station to the rest of the city area.

The hypothetical future network of conventional railway stations, based on a combination of all existing stations and future projected stations, can now be considered. Table 2 reveals the hypothetical potential of resident populations in accessibility zones generated for such stations. Compared to the existing configuration of railway stations and applying the same time accessibility zones (15 minutes), the overall population served would be more or less two-fold. In relative numbers, over $50 \%$ of the city population would reside in locations with a good access to railway stations. We should emphasise that the number of residents living in a comfortable 15-minute walking distance to the nearest station would increase considerably.

A general territorial picture of the hypothetical constellation of stations is presented in Figure 8. Evidently, the greatest potential for the resident populations can be observed in Petržalka, where the potential expressed by population mass would be even higher than for the Central station due to the large concentration of high-rise apartment houses. Any improvement of the high-capacity rail link with the city centre would improve the transport accessibility of Petržalka (Seidenglanz et al., 2016). Similarly, the projected Vrakuňa station might potentially have a high attractiveness due to housing developments in its neighbourhood.

The future Trnávka and Ružinov stations might profit from their positions in residential neighbourhoods characterised by both family and apartment houses. Moreover, large shopping areas and traditional industrial districts are located nearby. The projected Ružinov station will probably become a publictransport junction. The high attractiveness of the existing Lamač station will probably be reinforced in the future as this station might act as a principal public transport junction in the north-western sector of the city, allowing transfers between regional trains and city transport (trams).

\begin{tabular}{|c|c|c|c|c|c|c|}
\hline \multirow{3}{*}{ Railway stations } & \multicolumn{6}{|c|}{ Accessibility zones - numbers of residents } \\
\hline & \multicolumn{2}{|c|}{$0-1,000 \mathrm{~m}$} & \multicolumn{2}{|c|}{$1,001-2,000 \mathrm{~m}$} & \multicolumn{2}{|c|}{ Total $(0-2,000 \mathrm{~m})$} \\
\hline & abs. & rel. $(\%)$ & abs. & rel. $(\%)$ & abs. & rel. $(\%)$ \\
\hline Devínska Nová Ves & 2,392 & 0.58 & 457 & 0.11 & 2,853 & 0.69 \\
\hline Devínska Nová Ves-sídlisko & 9,561 & 2.32 & 560 & 0.14 & 10,120 & 2.46 \\
\hline Devínske Jazero & 0 & 0.00 & 52 & 0.01 & 52 & 0.01 \\
\hline Hlavná stanica & 6,663 & 1.62 & 18,554 & 4.51 & 25,216 & 6.13 \\
\hline Lamač & 5,560 & 1.35 & 14,288 & 3.47 & 19,848 & 4.83 \\
\hline Lamačská brána & 151 & 0.04 & 12,055 & 2.93 & 12,206 & 2.97 \\
\hline Mladá Garda & 3,235 & 0.79 & 3,122 & 0.76 & 6,357 & 1.55 \\
\hline Nové Mesto & 2,130 & 0.52 & 6,894 & 1.68 & 9,024 & 2.19 \\
\hline Patrónka & 1,843 & 0.45 & 3,708 & 0.90 & 5,551 & 1.35 \\
\hline Petržalka & 17,717 & 4.31 & 24,276 & 5.90 & 41,993 & 10.21 \\
\hline Podunajské Biskupice & 2,682 & 0.65 & 5,165 & 1.26 & 7,846 & 1.91 \\
\hline Predmestie & 1,217 & 0.30 & 188 & 0.05 & 1,405 & 0.34 \\
\hline$R a c ̌ a$ & 4,063 & 0.99 & 8,910 & 2.17 & 12,973 & 3.15 \\
\hline Rusovce & 1,460 & 0.35 & 892 & 0.22 & 2,351 & 0.57 \\
\hline Ružinov & 3,194 & 0.78 & 6,995 & 1.70 & 10,190 & 2.48 \\
\hline Trnávka & 9,849 & 2.39 & 4,771 & 1.16 & 14,620 & 3.56 \\
\hline Ústredná nákladná stanica & 983 & 0.24 & 7,076 & 1.72 & 8,059 & 1.96 \\
\hline Vajnory & 1,688 & 0.41 & 1,351 & 0.33 & 3,039 & 0.74 \\
\hline Vinohrady & 345 & 0.08 & 2,610 & 0.63 & 2,956 & 0.72 \\
\hline Vrakuňa & 10,396 & 2.53 & 12,116 & 2.95 & 22,512 & 5.47 \\
\hline Východ & 1,484 & 0.36 & 866 & 0.21 & 2,350 & 0.57 \\
\hline Total & 86,614 & 21.06 & 134,905 & 32.81 & 221,519 & $\mathbf{5 3 . 8 7}$ \\
\hline
\end{tabular}

Tab. 2: Number of residents in particular accessibility belts surrounding railway stations after upgrading of the city railway network (Variant 2). Source: authors' calculations based on the 2011 population census

Notes: Abs. = absolute numbers. Rel. = relative proportions; Relative values are derived from the total population of Bratislava; Stations in italics indicate projected stations and existing stations currently excluded from intra-urban railway transport. 


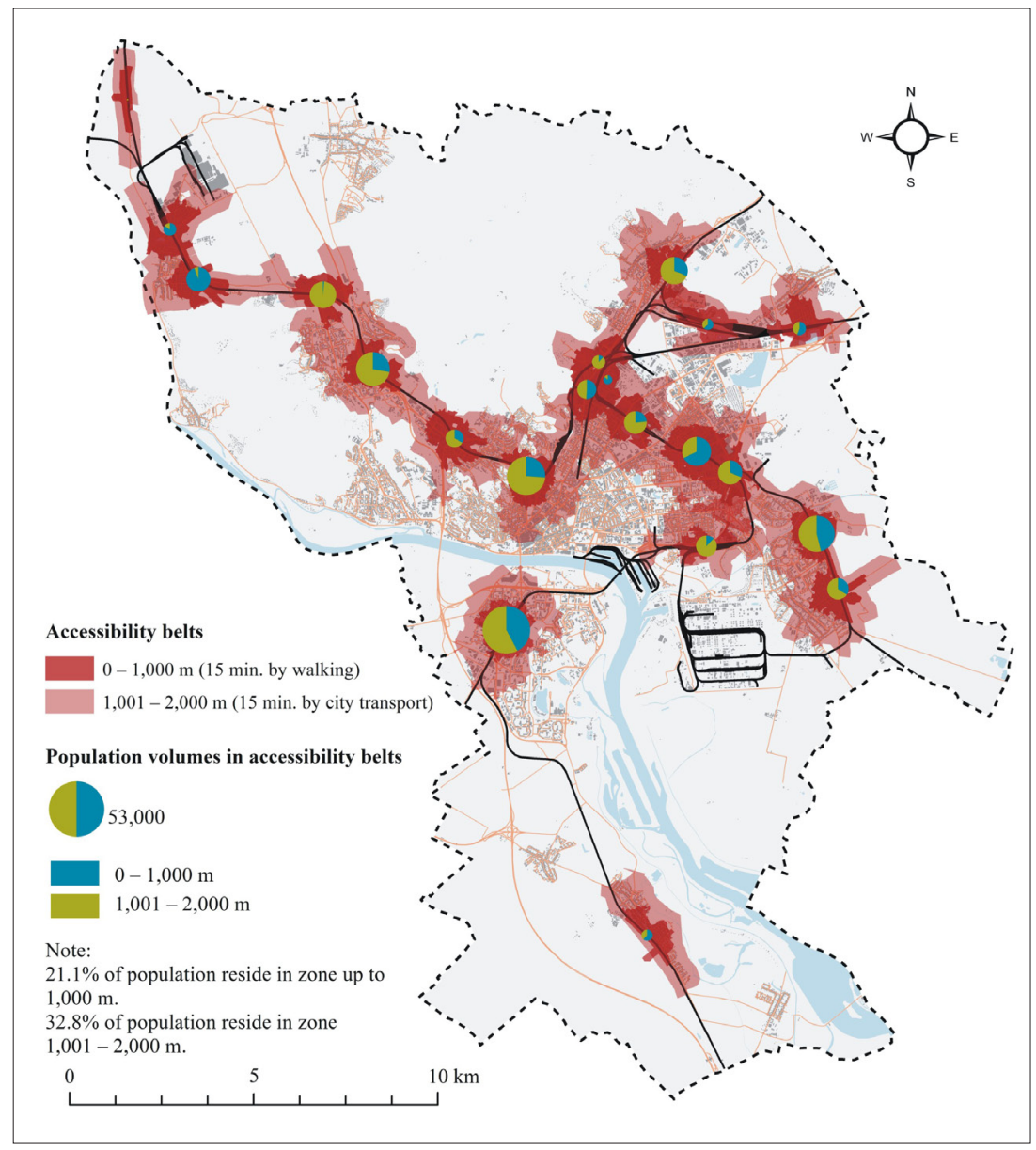

Fig. 8: Accessibility of railway stations after upgrading of the city railway network (Variant 2) Sources: Location of railway stations: CDV, 2016; ŽSR..., 2016; Map layers: MAPZEN, 2015

The rest of the new (projected) stations will either serve as public-transport transfer junctions (such as the projected Patrónka or Mladá Garda stations) or improve accessibility of some peripheral (suburban) districts of the city (Východ and Rusovce stations).

To summarise the projected configuration of railway stations in Bratislava, the possible improvement of accessibility stems basically from two different facts. First, the projected new stations (along the west-east intra-urban railway corridor) will considerably cover districts with high housing concentrations. Second, linking the southern radial railway with the city centre and the operation of intra-urban trains might improve the efficiency of railway connections between the densely populated Petržalka and northern and eastern districts.

\section{Conclusions}

Two main conclusions can be drawn from this project. First, we introduced an innovative approach to research on population distributions within an urban micro-environment. Second, the railway station network accessibility within the intra-urban area of Bratislava city was analysed here using our innovative approach.

The first finding concerns our approach aimed at detecting population distributions based on an existing residential buildings database. In countries like Slovakia, where an address points database concept has not been fully introduced or validated, this approach may be a helpful tool applicable to different fields of research (such as the distribution of employment opportunities, the spatial distribution of secondary school or university students, etc.). Kraft and Blažek (2012) state that these parameters are important if commuting to work or schools is researched, but the distribution of these activities in real space is hazy and very difficult to monitor. Our approach was applied to the railway infrastructure accessibility issue analysed in an urban environment, where a physical communication network was used to generate accessibility zones. The GIS package of Arc GIS 10.1 proved to be useful for our purposes.

Applications of this method are quite universal and may be fruitful in attempts aimed at the detection of accessibility zones to various points of interest (such as food stores, emergency centres, etc.). Similar attempts to detect various accessibility attributes related to the location of points of interest (such as transport points or services) have already been applied to the urban environment of Bratislava (see e.g. Kusendová and Štepitová, 2001; Križan and Tolmáči, 2008b; Križan, 2009; Križan et al., 2015) but without a relevant analytical approach to the actual distribution of the city residents.

Secondly, the empirical output of our research might be useful for a broader discussion on the effectiveness of existing and projected rail networks in the city of Bratislava, for bulky intra-urban (or regional) passenger transportation purposes. To show a possible shift between the existing and presumed constellation of conventional railway infrastructure in Bratislava, we made an effort to show different variants of the railway network accessibility. Currently, about one-quarter of Bratislava's population resides within 
a 15 minutes time accessibility (by either public transport or walking) to the nearest conventional railway station. If all currently projected railway stations are put into operation, this proportion could exceed $50 \%$ of the population, with considerable improvement of walking distance accessibility. In particular, the southern residential district of Petržalka would benefit from such an improvement.

Nevertheless, the territorial configuration of the existing railway infrastructure in the intra-urban environment of Bratislava city currently allows comfortable access to railways only for a limited portion of the city's area (even though the length of railway networks in the intra-urban area reaches over $80 \mathrm{~km}$ ). The projected upgrading of the city's railway network and the construction of new stations will improve the accessibility of railway infrastructure for many, but some parts of the city will still remain in poor accessibility conditions. This is surely the case for the Central Business District of Bratislava recently developed east of the city centre. Many authors (Ira, 2003; Korec, 2013) believe that this part of the city will increasingly become attractive for bulky commuter flows. The TEN-T 17 project of an underground railway corridor, which was supposed to improve railway accessibility to this part of the city, has recently been suspended (Horváth, 2012). The residential district of Bratislava-Karlova Ves in the western part of Bratislava is far from being connected to conventional railways, but here the shortage of railways is well compensated by an efficient light city train (tram) service. A certain upgrading of the tram network in the city is already under way. The remaining parts of the city (such as Bratislava-Čunovo, Bratislava-Jarovce, Bratislava-Záhorská Ves, Bratislava-Devín) will not see any considerable improvement of accessibility to railway stations in the forthcoming decades, but these districts are perceived as the periphery of the city (Slavík et al., 2011) and they are sparsely populated with low concentrations of residents.

The current paper presents only partial outputs for the problems, as the potential of the intra-urban railway infrastructure remains unsolved. Directions of flows potentially exploitable in the city railway network, as well as the attractiveness of individual railway stations, still remain untouched by further research.

The limitations of the current study are as follows:

- some disputable reliability of the 2011 population census in Slovakia;

- the census data may be outdated (as of 2011) and some locations with dynamic housing development might have witnessed considerable population changes;

- population masses calculated for the projected constellation of intra-urban railway network were based on the 2011 census data, omitting any detailed population forecast;

- errors concerning residential building identification: some of the buildings may be used also for other purposes (such as retailing business or small enterprises in the basements of the buildings);

- schematic conversion of population masses of BRUs onto residential buildings;

- simplification concerning the calculation of residential areas derived from ground-plot areas of individual buildings (including the average numbers of floors); and

- consideration of ideal mobility conditions within the urban environment, based on average walking speed, not respecting possible barriers and the variable capacities of communication linkages.

\begin{tabular}{lccc}
\hline Trajectory (initial point-target point) & Time (min) & Distance (km) & Speed (km/h) \\
\hline Hlavná stanica-Botanická & 14 & 5.7 & 26.3 \\
Hlavná stanica-Zochová & 5 & 1.6 & 19.2 \\
Račianskemýto-ŽST Vinohrady & 8 & 3.4 & 22.7 \\
Vyšehradská-Aupark & 12 & 5.0 & 25.0 \\
SAV-VW & 25 & 15.6 & 33.4 \\
Hlavná stanica-Autobusová stanica & 10 & 3.1 & 18.6 \\
Hlavná stanica-Nové SND & 13 & 4.0 & 18.5 \\
Čilížska-Cintorín Vrakuňa & 8 & 3.5 & 26.3 \\
Trnavské mýto-Cintorín slávičie údolie & 19 & 7.0 & 22.1 \\
Most SNP-Trnavské mýto & 12 & 2.9 & 13.4 \\
Park kultúry a oddychu-Račianske mýto & 12 & 3.5 & 16.2 \\
Trnavské mýto-Zlaté piesky & 14 & 5.6 & 22.4 \\
ŽST Vinohrady-Komisárky & 12 & 4.5 & 22.5 \\
Karlova Ves-Pri kríži & 10 & 3.9 & 23.4 \\
Patrónka-Lamač & 11 & 5.5 & 25.4 \\
Štefana Králika-Hradištná & 3 & 1.3 & 26.0 \\
Cintorín slávičie údolie-Molecová & 8 & 3.2 & 24.0 \\
Zlaté piesky-Vajnory-konečná & 11 & 5.1 & 27.8 \\
AVION-IKEA-Zimný štadión & 13 & 3.9 & 16.7 \\
\hline Total/Average & $\mathbf{2 2 0}$ & $\mathbf{8 8 . 3}$ & $\mathbf{2 4 . 1}$ \\
\hline
\end{tabular}

Annex 1: Travel speed of public transport based on authors' empirical research. Source: authors' field measurements Notes: detection carried out between 10:00-11:30 a. m., working days of Tuesday, Wednesday and Thursday; only direct connections (without interchanges) were recorded 


\section{Acknowledgement}

This paper was prepared thanks to support provided within the projects APVV-018-12 and VEGA-2/0089/15.

\section{References:}

GARAJOVÁ, A. (2015): Analýza vybraných demografických ukazovatel'ov základných sídelných jednotiek. Bratislava, Prif UK.

GARDNER, B., ABRAHAM, C. (2007): What drives car use? A grounded theory analysis of commuters reasons for driving. Transportation Research: Traffic Psychology, Behaviour, 10(3): 187-200.

GEURS, T., RITSEMA VAN ECK, R. (2001): Accessibility measures: review and applications. Utrecht, Urban Research Centre Utrecht University.

GEURS, T., VAN WEE, B. (2004): Accessibility evaluation of land-use, transport strategies: review, research directions. Journal of Transport Geography, 12(1): 127-140.

GIVONI, M., RIETVELD, P. (2007): The access journey to the railway station, its role in passengers' satisfaction with rail travel. Transport Policy, 14(5): 357-365.

HANDY, L., NIEMEIER, A. (1997): Measuring accessibility: an exploration of issues, alternatives. Environment, Planning, 29(4): 1175-1194.

HANSON, S., SCHWAB, M. (1987): Accessibility, intra-urban travel. Environment, Planning, 19(3): 735-748.

HARDI, T. (2012): Cross-border suburbanisation: The case of Bratislava. In: Csapó, T., et al. [eds.]: Development of the Settlement Network in the Central European Countries: Past, Present, Future (pp. 156-188). Berlin and Heidelberg, Springer Verlag.

HEJHALOVÁ, B. (2010): Štandardy kvality dopravnej obsluhy, ako nástoj zvyšovania atraktivity verejnej hromadnej osobnej dopravy v regiónoch. Doprava a spoje, 5(1): 84-98.

HELLING, A. (1998): Changing intra-metropolitan accessibility in the U.S.: Evidence from Atlanta. Progress in Planning, 49(2): 57-103

HENSHER, D. (2001): The valuation of commuter travel time savings for car drivers: evaluating alternative model specifications. Transportation, 28(2): 101-118.

HORÁK, J., PEŇÁZ, T., RUŽIČKA, L. (2004): Hodnocení dopravní dostupnosti zaměstnavatelů. In: Sbor. ref. medzinárodního symposia GIS Ostrava 2004 (pp. 1-16). Ostrava.

HORŇÁK, M. (2003): Niektoré aspekty rozmiestnenia obyvatel'stva SR vo vztahu k dostupnosti železničnej siete. Horizonty dopravy, 11(2): 25-27.

HORŇÁK, M. (2004): Rozmiestnenie obyvatel'stva vzhl'adom k železničnej sieti SR ako jeden $\mathrm{z}$ argumentov pre podporu rozvoja osobnej železničnej dopravy. Acta Geographica Universitatis Comenianae, 45(1): 27-37.

HORŇÁK, M. (2008): Význam dopravnej polohy v procese koncentrácie obyvatel'stva v Slovenskej republike. In: Kvizda, M. et al. [eds.]: Konkurencieschopnost a konkurence v železniční dopravě - ekonomické a regionální aspekty regulace konkurenčního prostředí (pp. 113-154). Brno, Masarykova univerzita.
HORVATH, L. (2012): Stane sa z projektu TEN-T realita? Dopravoprojekt [online] [cit. 12-12-2015]. Available at: http://www.dopravoprojekt.sk/sk/presscentrum/tlacovespravy-a-vyhlasenia/219-stane-sa-z-projektu-ten-t-realita

IRA, V. (2003): The changing intra-urban structure of the Bratislava city, its perception. Geografický časopis, 55(2): 91-108.

IVAN, I., TESLA, J. (2015): Road, intersection accidents: localization of black spots in Ostrava. Geografický časopis, 67(4): 323-340.

JIANG, B., CLARAMUNT, C., BATTY, M. (1999): Geometric accessibility, geographic information: extending desktop GIS to space syntax. Computers, Environment, Urban Systems, 23(1): 127-146.

KOREC, P. (2013): Ekonomická báza Bratislavy, jej vývoj a perspektívy, In: Buček, J., Korec, P.: Moderná humánna geografia mesta Bratislava: priestorové štruktúry, siete a procesy (pp. 119-147). Bratislava, Univerzita Komenského.

KOTAVAARA, O., ANTIKAINEN, H., RUSANEN, J. (2011): Population change, accessibility by road, rail networks: GIS, statistical approach to Finland 1970-2007. Journal of Transport Geography, 19(4): 926-935.

KRAFT, S., BLAŽEK, M. (2012): Intraurbánní dostupnost zastávek městské hromadné dopravy a její hodnocení pomocí nástrojů GIS. In: Bartołomiejczyk, M. et al. [eds.]: Vybrané aspekty provozování veřejné dopravy ve stř̌ední a východní Evropě - Př́́klady z České republiky, Polska a Slovenska (pp. 47-60).Katowice, Polskie Towarzystwo Geograficzne, Oddzial Katowicki, Sosnowiec.

KRIŽAN, F. (2009): Dostupnost’ vybraných zariadení služieb na území mesta Bratislava aplikáciou miery založenej na príležitostiach. Acta Geographica Universitatis Comenianae, 53(2): 149-167.

KRIŽAN, F., BILKOVÁ, K., KITA, P., KUNC, J., BARLÍK, P. (2015): Nákupné centrá v Bratislave a atribúty ovplyvňujúce preferencie spotrebitel'ov. Geografický časopis, 67(4): 341-357.

KRIŽAN, F., GURŇÁK, D. (2008): Vybrané kartografické a grafické metódy znázorňovania dostupnosti. Acta Geographica Universitatis Comenianae, 51(1): 71-78.

KRIŽAN, F., TOLMÁČI, L. (2008a): Intraurbárna dostupnost’ železničných staníc na území mesta Bratislava. Železničná doprava a logistika, 4(3): 22-28.

KRIŽAN, F., TOLMÁČI, L. (2008b): Meranie priestorovej dostupnosti pôšt na území mesta Bratislava pomocou percepčných mier dostupnosti. Pošta, Telekomunikácie a Elektronický obchod, 3(2): 33-42.

KUSENDOVÁ, D. (2002): Aplikácia vzdialenostných operátorov GIS v demografických analýzach. Sbor. ref. medzinárodního symposia GIS Ostrava 2002 [online] [cit. 04-02-2016]. Available at: http://gis.vsb. cz/GIS_Ostrava/GIS_Ova_2002/Sbornik/Referaty/ kusendovar.htm

KUSENDOVÁ, D., SZABOVÁ, M. (1998): Vzdialenostné a sietové analýzy-analytické nástroje GIS. Kartografické listy, 6(1): 101-110.

KUSENDOVÁ, D., ŠTEPITOVÁ, D. (2001): Použitie nástrojov GIS v obchodno-služobnej aplikácii bankomatové prevádzky v centre Bratislavy. Sbor.ref. 
medzinárodního symposia GIS Ostrava 2001 [online] [cit. 04-04-2016]. Available at: http://gis.vsb.cz/GIS_Ostrava/ GIS_Ova_2001/Sbornik/Referaty/kusendova.htm

KWAN, M. (1998): Space-time, integral measures of individual accessibility: a comparative analysis using a point-based framework. Geographical Analysis, 30(3): 191-216.

LANE, B. (2008): Significant characteristics of the urban rail renaissance in the United States: A discriminant analysis. Transportation Research Part A: Policy, Practice, 42(2): 279-295.

MAPZEN (2015): Metro extracts - Vienna, Bratislava [online] [cit. 12-12-2015]. Available at: https:/mapzen. com/data/metro-extracts

MARADA, M., KVĚTOŇ, V. (2010): Diferenciace nabídky dopravních přiležitostí $\mathrm{v}$ českých obcích a sociogeografických mikroregionech. Geografie-Sborník ČGS, 115(1): 21-43.

MICHNIAK, D. (2003): Dostupnost’ okresných miest na Slovensku. Geografický časopis, 55(1): 21-39.

MICHNIAK, D. (2006): Accessibility of the railway network in Slovakia. Europa XXI, 15(1): 51-61.

MICHNIAK, D. (2014): Vybrané prístupy k hodnoteniu dopravnej dostupnosti vo vztahu $\mathrm{k}$ rozvoju cestovného ruchu. Geografický časopis, 66(1): 21-38.

MORRIS, M., DUMBLE, L., WIGAN, R. (1979): Accessibility indicators for transport planning. Transportation Research, 13(1): 91-109.

OpenStreetMap (2015): maps [online] [cit. 12-12-2015]. Available at: www.openstreetmap.org

PETERS, D. (2009): The renaissance of inner-city rail station areas: a key element in contemporary urban restructuring dynamics. Critical Planning, 10(2): 163-185.

PETERS, D. (2010): Digging through the heart of reunified Berlin: Unbundling the decision-making process for the tiergarten-tunnel mega-project. The European Journal of Transport, Infrastructure Research, 10(1): 89-102.
PODMANICKÁ, Z., ŠKÁPIK, P., KRČMÉRYOVÁ, E., JUHAŠČ́́KOVÁ, I., ŠTUKOVSKÁ, Z., RADOVÁ, V., KOTLÁR, J., SMUTNÁ, K. (2014): Štatistický lexikón obcí Slovenskej republiky 2011. Bratislava, ŠÚSR.

PŠENKA, T. (2009): Faktory vplývajúce na vývoj železničnej siete Slovenska. Acta Geographica Universitatis Comenianae, 53(2): 47-60.

SEIDENGLANZ, D., KVIZDA, M., NIGRIN, T., TOMEŠ, Z., DUJKA, J. (2016): Czechoslovak light rail - Legacy of socialist urbanism or opportunity for the future? Journal of Transport Geography, 54: 414-429.

SLAVÍK, V., KLUBUČNÍK, M., KOHÚTOVÁ, K. (2011): Vývoj rezidenčnej suburbanizácie $\mathrm{v}$ regióne Bratislava v rokoch 1990-2009. Forum Statisticum Slovacum, $7(6): 169-175$.

ŠVEDA, M. (2011): Suburbanizácia v zázemí Bratisalvy z hladisak analýzy zmien krajinnej pokrývky. Geografický časopis, 63(2): 155-173.

WHITEHAND, J. (1967): Fringe belts: neglected aspects of urban geography. Transactions, Institute of British Geographers, 41(1): 223-233.

WILLIGERS, J., HAN, F., VAN WEE, B. (2007): Accessibility indicators for location choices of offices: an application to the intraregional distributive effects of high-speed rail in the Netherlands. Environment, Planning, 39(4): 2086-2098.

ZHANG, M., SHEN, Q., SUSSMAN, J. (1998): Job Accessibility in the San Juan Metropolitan Region: Implications for Rail Transit Benefit Analysis. Transportation Research Record: Journal of the Transportation Research Board, 1618(1): 22-45.

ŽSR, Terminály integrovanej osobnej prepravy v Bratislave, úsek Devínska Nová Ves-Bratislava-Hlavná stanicaPodunajské Biskupice (2016). Database of Railways of the Slovak Republic[online] [cit. 03-05-2016]. Available at: http://www.zsr.sk/slovensky/projekty-eu/tiop-v-badnv-pb.html?page_id $=3142$ in Bratislava (Slovakia). Moravian Geographical Reports, 24(4): 52-64. Doi: 10.1515/mgr-2016-0022. 